\title{
Talc-Based Bioformulations of Fluorescent Pseudomonads for the Management of Coleus and Ashwagandha Root Diseases
}

\author{
S.B. Mallesh ${ }^{1 *}$, R.P. Jaiprakash Narayan ${ }^{2}$ and Mallikarjun Dhotre ${ }^{2}$ \\ ${ }^{1}$ Department of Plant Pathology, University of Agricultural Sciences, Raichur, India \\ ${ }^{2}$ College of Agriculture, Bheemarayanagudi - 585 287, India \\ *Corresponding author
}

\section{A B S T R A C T}

\begin{tabular}{|c|}
\hline Keywords \\
\hline $\begin{array}{l}\text { Fluorescent } \\
\text { Pseudomonads, } \\
\text { Medicinal plants, Talc- } \\
\text { based bioformulations, } \\
\text { Disease management }\end{array}$ \\
\hline Article Info \\
\hline $\begin{array}{l}\text { Accepted: } \\
30 \text { March } 2018 \\
\text { Available Online: } \\
10 \text { April } 2018\end{array}$ \\
\hline
\end{tabular}

\section{Introduction}

Coleus (Coleus forskohlii) and Ashwagandha (Withania somnifera) are the most important potential medicinal crops of the future, as its pharmacological properties have been discovered recently. Tuberous roots of Coleus forskohlii resembling carrot in shape and brown in colour contain a diterpenoid forskolin (Syn. Coleonol) (Shah, et al., 1980) an important constituent which ranges from 0.1 to 0.8 per cent (Valdes et al., 1987). The Indian herb C. forskohlii is the only known source of forskolin (De Sauza and Shah, 1988). Ashwagandha is regarded as the
Plant growth promoting rhizobacteria (PGPR) were isolated from rhizospheres of coleus (Coleus forskohlii) and ashwagandha (Withania somnifera) from different parts of Karnataka. Isolated PGPR strains were screened for their efficacy against three soil-borne pathogens like Fusarium, Ralstonia and Meloidogyne in coleus and ashwagandha. two pathens. Plant growth promoting activity of rhizobacteria having been tested, their phenotypic as well as biochemical characterization of these potent PGPR strains showed them to be fluorescent pseudomonads. Talc-based bioformulations of these fluorescent pseudomonads were utilized in replicated pot and field experiments to determine their efficacy to suppress the disease complex and enhance plant growth parameters of coleus and strains RB-50 and RB-31 decreased root knot index and incidence of disease complex while increasing plant height, number of branches, fresh and dry biomass; tuber yield in respect of both coleus and ashwagandha. 
Ralstonia solanacearum and root-knot by Meloidogyne incognita. Many effective pesticides have been tested against soil borne pathogens but not considered as long term solution because of concerns about exposure risks, health and environmental hazards, expensiveness, residue persistence, development of resistance to pesticides and elimination of natural enemies.

Therefore, a need for alternative methods of control of soil borne pathogens has become vital. Unfortunately, there are no effective ecologically sound multiple disease management practices especially for nematodes. Development of biological control for soil borne diseases is accepted as a durable and ecofriendly alternative for agrochemicals.

\section{Materials and Methods}

A systematic study was undertaken to isolate native strains of rhizobacteria from major coleus and ashwagandha growing areas of Karnataka, in order to test their efficacy against different pathogens affecting these crops, their mechanisms of biocontrol and plant growth promotion was assessed. The experiments were carried out Department of Plant Pathology, College of Agriculture, Bheemarayanagudi University of Agricultural Sciences, Raichur.

Samples of soil and root system from healthy rhizosphere of coleus and ashwagandha were collected from ten plants each at random from each field. Each sample consisted of $100 \mathrm{~g}$ soil and $10 \mathrm{~g}$ roots. Rhizobacteria were isolated from rhizospheres of coleus and ashwagandha crops. Colonies that came up on $\mathrm{KB}$ plates were observed under UV light on a transilluminator. The colonies fluorescing under UV light were picked up, purified and preserved. Representative colonies on the NA plates were picked up, purified and preserved in nutrient broth. These strains were maintained at $-80^{\circ} \mathrm{C}$ with 50 per cent glycerol The predominant pathogens of coleus and ashwagandha were isolated by tissue isolation technique. Isolated pathogens like Fusarium chlamydosporum, Ralstonia solanacearum and root-knot by Meloidogyne incognita were maintained in pure culture in the laboratory as well as in the glasshouse.

In vitro screening of rhizobacteria against Fusarium and Ralstonia

Fifty rhizobacterial strains isolated were tested for their inhibitory activity against mycelial growth of Fusarium and Ralstonia by following the dual culture technique (Dennis and Webster, 1971). Each treatment was replicated three times. After incubation, i.e. when control plate reached $90 \mathrm{~mm}$ diameter, the radial growth of pathogen was measured. Per cent inhibition over control was calculated by using the formula of Vincent (1947) as follows;

$\mathrm{I}=\mathrm{C}-\mathrm{T} / \mathrm{C} \mathrm{X} 100$

Where, I = Per cent inhibition of mycelium, $\mathrm{C}=$ Growth of mycelium in control and $\mathrm{T}=$ Growth of mycelium in treatment.

\section{Morphological characterization}

Seven selected efficient PGPR strains were examined for the colony morphology, growth, pigmentation, cell shape and gram reaction as per the standard procedures given by Anonymous (1957) and Barthalomew and Mittewer (1950).

\section{Biochemical characterization of PGPR strains}

The biochemical characterization of selected efficient PGPR strains was essentially done as per the procedures outlined by Cappuccino and Sherman (1992). 
Preparation of talc-based formulations of PGPR strains

A loopful of different PGPR strains was inoculated to nutrient broth separately and incubated in a rotary shaker at $150 \mathrm{rpm}$ for 48 $\mathrm{h}$ at room temperature $\left(28 \pm 2^{\circ} \mathrm{C}\right)$. After $48 \mathrm{~h}$ of incubation, the broth containing $9 \times 10^{8}$ $\mathrm{cfu} / \mathrm{ml}$ was used for the preparation of talcbased formulation.

To $400 \mathrm{ml}$ of bacterial suspension, one $\mathrm{kg}$ of the purified talc powder (sterilized at $105^{\circ} \mathrm{C}$ for $12 \mathrm{~h}$ ) $15 \mathrm{~g}$ calcium carbonate (to adjust the $\mathrm{pH}$ to neutral) and $10 \mathrm{~g}$ of carboxy methyl cellulose (CMC) as an adhesive were mixed under aseptic conditions following the method described by Vidhyasekaran and Muthamilan (1995).

The product was shade dried to reduce the moisture content below 20 per cent and then packed in polythene bags and sealed. At the time of application, the population of the bacteria in talc formulation was checked to 2.5 to $3 \times 10^{8} \mathrm{cfu} / \mathrm{g}$.

\section{Evaluation of fluorescent pseudomonads under field conditions}

An experiment was conducted with eight treatments and three replications for coleus and ashwagandha in randomized block design was used. The soil was naturally infested with Fusarium and Meloidogyne with a population density of more than one (1.5) nematode per $\mathrm{CC}$ of soil. The treatment details are as follows: $\mathrm{T}_{1}-\mathrm{RB} 1, \mathrm{~T}_{2}-\mathrm{RB10}, \mathrm{T}_{3}-\mathrm{RB} 13, \mathrm{~T}_{4}$ - RB22, $\mathrm{T}_{5}-\mathrm{RB} 31, \mathrm{~T}_{6}-\mathrm{RB} 43, \mathrm{~T}_{7}-\mathrm{RB} 50$ and $\mathrm{T}_{8}-$ control.

Selected efficient PGPR strains were mass multiplied on talc based bio formulations and the seedlings and seeds of coleus and ashwagandha were treated with this Pseudomonads cultures.
Observations like plant growth parameter at different growth stages $(60,90,150 \mathrm{DAP}$ and at harvest) plant height, number of branches and per cent wilt incidence and at harvest yield parameters like weight of tubers, length and number of tubers, fresh and dry weight total biomass and yield were recorded.

\section{Results and Discussion}

Isolation of PGPR strains from different locations help to identify the organisms that are suited to varied nutrient and environmental conditions. In the present study, fifty rhizobacterial strains were isolated from six districts of Karnataka in coleus and ashwagandha rhizosphere, viz. Bijapur, Belgaum, Dharwad, Uttara Kannada, Tumkur and Bangalore. Similarly, most of the research workers have isolated fluorescent pseudomonads from varying ecosystems. Among many of the fluorescent pseudomonads, P. fluorescens was isolated predominantly from natural soils for the management of soil borne and foliar diseases (Weller et al., 2002). A similar study conducted by Jonathan et al., (2005) to isolate rhizobacteria in the rhizosphere of betelvine in Tamil Nadu, revealed the presence of fluorescent pseudomonads and other beneficial rhizobacteria.

Fifty rhizobacterial strains isolated from different ecosystem of Karnataka in coleus and ashwagandha were subjected to in vitro screening against soil borne and wilt complex pathogens: Fusarium, Ralstonia and Meloidogyne of coleus and ashwagandha. Of the 50 rhizobacterial strains screened against Fusarium, Ralstonia and Meloidogyne of coleus and ashwagandha in dual cultural techniques, the results revealed that nineteen strains were highly effective in inhibiting the mycelial growth of the test pathogen to an extent of 75.00 per cent and above were selected (Table 1). 
Table.1 Morphological, biochemical characterization and identification of the selected PGPR strains

\begin{tabular}{|c|c|c|c|c|c|c|c|c|c|c|c|c|c|c|c|c|}
\hline \multirow{2}{*}{$\begin{array}{l}\text { PGPR } \\
\text { strains }\end{array}$} & \multicolumn{5}{|c|}{ Morphological } & \multicolumn{10}{|c|}{ Biochemical } & \multirow{2}{*}{$\begin{array}{l}\text { Assigned } \\
\text { genus }\end{array}$} \\
\hline & YPKB & FLUV & GR & CS & SF & GL & SH & CA & $\mathbf{C H}$ & $\mathbf{L H}$ & AGP & HSP & UP & $\mathrm{G} 4^{0} \mathrm{C}$ & $\mathrm{G} 41^{\circ} \mathrm{C}$ & \\
\hline RB1 & + & + & - & Long rod & - & + & - & + & + & + & + & + & + & - & + & Pseudomonas \\
\hline RB10 & - & + & - & Rod & - & + & - & + & + & + & + & + & + & - & + & Pseudomonas \\
\hline RB13 & + & + & - & Rod & - & + & - & + & + & + & + & + & + & - & + & Pseudomonas \\
\hline RB22 & - & + & - & Rod & - & + & - & + & + & + & + & + & + & - & + & Pseudomonas \\
\hline RB31 & + & + & - & Short Rod & - & + & - & + & + & + & + & + & + & - & + & Pseudomonas \\
\hline RB43 & + & + & - & Long Rod & - & + & - & + & + & + & + & + & + & - & + & Pseudomonas \\
\hline RB50 & + & + & - & Short Rod & - & + & - & + & + & + & + & + & + & - & + & Pseudomonas \\
\hline
\end{tabular}

+ Positive and - Negative

YPKB- Yellow pigmentation on KB, FLUV- Fluorescence under UV, GR- Gram Reaction, CS- Cell Shape, SF - Spore formation, GL- Gelatin Liquefaction,

SH- Starch Hydrolysis CA- Catalase Activity, CH- Casein Hydrolysis, LH- Lipid Hydrolysis, AGP- Acid and Gas Production, UP- Urease Production : G

$4^{\circ} \& 41^{\circ} \mathrm{C}$ - Growth at 4 and $41^{\circ} \mathrm{C}$

Table.2 Efficacy of talc formulations of PGPR strains on yield parameters and disease incidence in coleus under field conditions

\begin{tabular}{|c|c|c|c|c|c|c|c|c|c|c|c|c|}
\hline \multirow[t]{2}{*}{$\begin{array}{l}\text { PGPR } \\
\text { strains }\end{array}$} & \multirow[t]{2}{*}{$\begin{array}{c}\text { Tubers/ } \\
\text { plant }\end{array}$} & \multicolumn{3}{|c|}{ Tubers } & \multicolumn{2}{|c|}{ Shoot weight (g) } & \multicolumn{2}{|c|}{$\begin{array}{c}\text { Total Biomass } \\
(\mathrm{g})\end{array}$} & \multirow{2}{*}{$\begin{array}{l}\text { Root } \\
\text { knot } \\
\text { index }\end{array}$} & \multirow{2}{*}{$\begin{array}{l}\text { Per cent } \\
\text { disease } \\
\text { incidence }\end{array}$} & \multirow{2}{*}{$\begin{array}{l}\text { Per cent } \\
\text { decrease } \\
\text { over } \\
\text { control }\end{array}$} & \multirow{2}{*}{$\begin{array}{l}\text { Tuber Yield } \\
\text { (fresh } \\
\text { weight kg/ } \\
\text { plot) }\end{array}$} \\
\hline & & $\begin{array}{l}\text { Length } \\
(\mathrm{cm})\end{array}$ & $\begin{array}{c}\text { Fresh } \\
\text { weight (g) }\end{array}$ & $\begin{array}{c}\text { Dry weight } \\
\text { (g) }\end{array}$ & Fresh & Dry & Fresh & Dry & & & & \\
\hline RB 01 & 15.25 & 22.45 & 209.27 & 36.78 & 755.17 & 109.83 & 9.64 .44 & 127.61 & 1.13 & 16.67 & 41.05 & 4.18 \\
\hline RB10 & 12.87 & 19.33 & 173.30 & 31.50 & 649.83 & 68.05 & 823.13 & 99.55 & 1.60 & 25.00 & 11.75 & 3.25 \\
\hline RB13 & 16.63 & 23.17 & 230.01 & 50.02 & 786.73 & 119.83 & 1016.74 & 169.85 & 0.80 & 20.00 & 29.40 & 4.60 \\
\hline RB22 & 11.87 & 18.57 & 168.17 & 31.17 & 613.67 & 57.43 & 811.84 & 88.6 & 1.53 & 23.33 & 17.64 & 3.36 \\
\hline RB31 & 16.50 & 29.28 & 272.46 & 62.29 & 822.08 & 128.60 & 1094.54 & 190.89 & 0.73 & 13.33 & 52.94 & 5.45 \\
\hline RB43 & 14.92 & 19.58 & 198.00 & 36.33 & 643.83 & 76.17 & 841.83 & 112.50 & 1.33 & 18.33 & 41.05 & 3.95 \\
\hline RB50 & 18.00 & 31.68 & 342.02 & 74.17 & 901.00 & 138.10 & 1243.02 & 212.27 & 0.66 & 10.00 & 64.70 & 6.74 \\
\hline Control & 10.70 & 17.59 & 145.77 & 30.00 & 584.67 & 48.00 & 730.44 & 80.00 & 2.20 & 28.33 & - & 3.00 \\
\hline SEm \pm & 0.50 & 0.58 & 0.58 & 1.19 & 3.72 & 2.17 & 4.83 & 2.16 & 0.21 & 1.65 & & 0.26 \\
\hline $\begin{array}{c}\text { CD@ } \\
5 \%\end{array}$ & 1.52 & 1.75 & 1.75 & 3.59 & 11.32 & 6.59 & 14.66 & 6.55 & 0.65 & 5.02 & & 0.79 \\
\hline
\end{tabular}


Table.3 Efficacy of talc formulations of PGPR strains on yield parameters and disease incidence in ashwagandha under field conditions

\begin{tabular}{|c|c|c|c|c|c|c|c|c|c|c|c|c|}
\hline \multirow[t]{2}{*}{ PGPR strains } & \multicolumn{3}{|c|}{ Root weight (g) } & \multicolumn{2}{|c|}{ Shoot weight (g) } & \multicolumn{2}{|c|}{$\begin{array}{c}\text { Total Biomass } \\
\text { (g) }\end{array}$} & \multirow{2}{*}{$\begin{array}{l}\text { Root } \\
\text { knot } \\
\text { index }\end{array}$} & \multirow{2}{*}{$\begin{array}{l}\text { Per cent } \\
\text { disease } \\
\text { incidence }\end{array}$} & \multirow{2}{*}{$\begin{array}{l}\text { Per cent } \\
\text { decrease } \\
\text { over } \\
\text { control }\end{array}$} & \multirow{2}{*}{$\begin{array}{l}\text { Berry wt. } \\
\text { (fresh wt. } \\
\text { g/ plant) }\end{array}$} & \multirow{2}{*}{$\begin{array}{l}\text { Root yield } \\
\text { (fresh } \\
\text { weight g/ } \\
\text { plot) }\end{array}$} \\
\hline & $\begin{array}{c}\text { Length } \\
\text { (cm) }\end{array}$ & $\begin{array}{c}\text { Fresh } \\
\text { (g) }\end{array}$ & Dry & $\begin{array}{l}\text { Fresh } \\
\text { weight }\end{array}$ & $\begin{array}{c}\text { Dry } \\
\text { weight }\end{array}$ & Fresh & Dry & & & & & \\
\hline RB 01 & 15.10 & 13.98 & 5.67 & 152.67 & 58.17 & 166.65 & 63.84 & 1.33 & 13.13 & 58.54 & 73.56 & 279.67 \\
\hline RB10 & 14.67 & 12.20 & 5.50 & 132.80 & 45.80 & 144.00 & 51.30 & 1.93 & 26.67 & 15.78 & 38.19 & 210.00 \\
\hline RB13 & 15.73 & 15.98 & 5.80 & 170.17 & 60.60 & 186.15 & 66.40 & 1.00 & 16.67 & 47.36 & 61.32 & 319.60 \\
\hline RB22 & 11.50 & 10.43 & 4.50 & 125.33 & 48.33 & 135.83 & 50.83 & 1.46 & 23.33 & 26.33 & 40.00 & 214.00 \\
\hline RB31 & 16.20 & 17.13 & 6.00 & 184.47 & 77.78 & 200.20 & 83.78 & 0.80 & 11.67 & 63.15 & 87.38 & 354.60 \\
\hline RB43 & 15.57 & 12.64 & 5.25 & 145.83 & 64.50 & 158.47 & 69.75 & 1.40 & 18.33 & 42.12 & 63.44 & 252.80 \\
\hline RB50 & 16.83 & 18.65 & 6.50 & 206.67 & 80.95 & 225.32 & 87.45 & 0.75 & 08.33 & 73.69 & 97.00 & 373.00 \\
\hline Control & 11.00 & 8.53 & 3.25 & 103.33 & 43.57 & 111.86 & 46.92 & 3.06 & 31.67 & - & 35.13 & 185.60 \\
\hline SEm \pm & 0.79 & 0.80 & 0.35 & 2.67 & 1.88 & 6.47 & 2.94 & 0.32 & 1.38 & - & 3.01 & 5.91 \\
\hline CD@5\% & 2.39 & 2.43 & 1.07 & 8.11 & 5.71 & 19.62 & 8.91 & 0.97 & 4.19 & - & 9.14 & 17.92 \\
\hline
\end{tabular}


Seven efficient PGPR strains that were selected based on in vitro, efficacy against Fusarium, Ralstonia and Meloidogyne were subjected to morphological and biochemical tests for identification. Morphological and biochemical characterization of the PGPR strains revealed that, they belonged to the genus Pseudomonas. All these were gram negative, rod shaped and had the ability to produce water soluble yellow green pigment. Further, these showed production of fluorescence under UV tested, positive for gelatin liquefaction, casein hydrolysis, lipid hydrolysis, catalase activity, acid and gas production, hydrogen sulphide production, urease activity and grew at $41{ }^{\circ} \mathrm{C}$. They treated negative for spore formation, starch hydrolysis and growth at $4{ }^{\circ} \mathrm{C}$.

\section{Disease incidence}

\section{Root-knot index}

In coleus, highest root knot index (RKI) 2.20 was recorded in untreated control followed by RB10. Lowest RKI was noticed in RB 50, RB31 and RB13 which showed 70.00, 66.81 and 63.63 per cent reduction in root-knot index respectively. No significant difference was observed among different strains. In ashwagandha, lowest root-knot index of 0.75 followed by 0.80 was recorded in RB50 and RB31. These two treatments were on par with each other. Highest RKI was recorded in untreated control followed by RB10 treated plants. In general, there was a drastic reduction in RKI due to PGPR treatments compared to untreated (Table 2 and 3 ).

In ashwagandha, there was significant reduction in disease incidence in PGPR treated plots when compared to untreated plots. In PGPR treatments RB50 recorded the lowest disease incidence of 8.33 per cent, followed by RB31. Highest disease incidence of 31.66 was recorded in untreated control

\section{Wilt complex incidence}

In coleus, lowest disease incidence of 10.00 per cent (64.70\% reduction over control) was recorded in RB50 followed by 13.33 per cent of RB31. Highest disease incidence of 28.33 per cent was recorded in untreated control followed by 25.00 per cent in RB10 treated plants. In general due to PGPR treatment there was reduction of disease incidence in coleus which varied from 64.70 to 11.75 per cent reduction over control respectively. In ashwagandha, there was significant reduction in disease incidence in PGPR treated plots when compared to untreated plots. In PGPR treatments RB50 recorded the lowest disease incidence of 8.33 per cent, followed by RB31. Highest disease incidence of 31.66 was recorded in untreated control.

The bioefficacy studies conducted in pot culture and field experiment indicated the efficacy of the talc formulations of PGPR strains in enhancing the plant growth parameters as they exhibited higher antagonistic activity against different pathogens and their combinations. Bioformulations containing RB50 and RB31 effectively reduced the disease incidence and root-knot infestation in coleus and ashwagandha than other treatments and untreated control in glasshouse and field conditions. Increase in yield under field conditions in RB50 and RB31 treated plants was significantly higher than the untreated control. Similar results were recorded in the studies conducted by Dunne et al., (1998), Duffy et al., (1996) in rice and Oostendorp and Sikora (1989) in sugarbeet.

\section{References}

Anonymous. 1957. Manual of Microbiological Methods, McGraw Hill Book Co., Inc., New York, p.127. 
Barthalomew, J. W., and Mittewer, T. 1950. A simplified bacterial strain, Stain Technique, 25: 153-158.

Cappuccino, J. G., and Sherman, N. 1992. Microbiology: A Laboratory Manual. The Bejamin/Cummings Publishing Company, Inc., California.

De Souza, N. J., and Shah, V. 1988. Forskolin An adenylate cyclase activating drug from Indian herb. In: Economic and Medicinal Plant Research, Vol. 2, Academic Press Ltd., New York.

Dennis, C., and Webster, J. 1971. Antagonistic properties of speciesgroups of Trichoderma 1, production of non-volatile antibiotics. Trans. British Mycological Society, 57: 25-39.

Duffy, B. K., Simon, A. and Weller, D. M. 1996. Combination of Trichoderma koningii with fluorescent Pseudomonads for control of Take all on wheat. Phytopathology, 86: 188-194.

Dunne, C. Cronin, D., Moknne-Loccoz, Gara, F. O. 1998. Biological control of phytopathogens by phloroglucinol and hydrolytic enzyme producing bacterial inoculants. Bulletin OILB/SROP, 21: 19-25.

Farooqi, A. A. Iqbal Ahmad, Aquil, F., and Ahmad, L. 2003. Broad-spectrum antibacterial and antifungal properties of certain traditionally used Indian medicinal plants. World Journal of Microbiology and Biotechnology, 19: 653-657.

Jonathan, E. I. Samiyappan, R. Bommaraju, P., and Amutha, G. 2005. Management of root knot nematode, Meloidogyne incognita and Phytophthora wilt complex in betelvine with plant growth promoting rhizobacteira. In: Proceedings of National Seminar on Emerging Trends in Plant Pathology and their Social Relevance, held at Annamalai Univ., Chidambaram, Tamil Nadu, India, March 7-8, 2005 p.52.

Oostendorp, M., and Sikora, R.A. 1989. Seed treatment with antagonistic rhizobacteria for the suppression of Heterodera schachtii early root infection by sugarbeet. Revue de Nematologie, 12: 77-83.

Shah, V. B. Bajwa, S. V. Dornaveer and De Souza, N. J. 1980. The occurrence of Forskolin in the labiatae. Plantation and Medicinal Plants, 39: 183-185.

Valdes, L. J. Mislankars, S. G., and Paul, A. G. 1987. Coleus barbatus (Lamiceae) and the potential new drug forskolin (Colenol). Ecology and Botany. 41: 474-483.

Vidyasekaran, P., and Muthamilan, M. 1995. Development of formulations of Pseudomonas fluorescens for control of chickpea wilt. Plant Disease. 79:782786.

Vincent, J. M. 1947. Distortion of fungal hyphae in the presence of certain inhibitors. Nature, 150: 850.

Weller, D. M., Raaijmakers, J. M., McSpadden Gardener, B. B., and Thomashow, L. S. 2000. Microbial populations responsible for specific soil suppressiveness to plant pathogens. Annual Review of Phytopathology, 40: 309-348.

\section{How to cite this article:}

Mallesh, S.B., R.P. Jaiprakash Narayan and Mallikarjun Dhotre. 2018. Talc-Based Bioformulations of Fluorescent Pseudomonads for the Management of Coleus and Ashwagandha Root Diseases. Int.J.Curr.Microbiol.App.Sci. 7(04): 3790-3796. doi: https://doi.org/10.20546/ijcmas.2018.704.427 